\title{
Hey That's Love Story!
}

\author{
by Audrey A. Hartley \\ Assistant Reference Librarian \\ Appalachian State University
}

Library orientation can be a real headache for students, as well as librarians or media specialists. Various institutions have set up classes which are instructed by librarians and carry one hour of credit for freshmen and transfer students. Unfortunately, too often the students do not take the course or tour seriously. They place little value upon its content and simply do not pay close attention.

Slide-tape tours and pamphlet tours of the library and its resources may also be found as a part of freshmen or fall orientation programs. A set of 44 slides and a programmed tape were devised for Appalachian State University's Belk Library in 1972. Schedules were set for the programs to be shown, and advertisement was provided by the campus newspaper, the local radio station, and memoranda were sent to various department chairmen. Several viewers, other than library personnel viewed the slides, but they said it was difficult to associate locations seen on the slides with the actual floor plan of the building. They also felt the program was too general and did not show "how to use the materials" mentioned.

As an alternative, a pamphlet was planned so that a patron could pick it up, read the instructions and take his own tour of Belk Library. Again people felt it was too general, and they were distracted by having to read as they walked along and were limited as to what they could explore. It seemed that library orientation was waning, so we reverted to the "class tour led by librarians." This approach did not allow time for the students to examine the materials discussed, and it was difficult for everyone in large groups to hear. Students were encouraged to stay after being dismissed to examine ma- terials discussed and ask questions; however, they were too bored by this time or had to rush to get to their next class.

It is apparent that effective library instruction takes place when the patron is most in need of help in finding information for a report or an answer to a particular question. With this in mind, programmed tapes have been developed for Belk Library which tell how to use READER'S GUIDE, ERIC, EDUCATION INDEX, MONTHLY CATALOG OF GOVERNMENT PUBLICATIONS, and NEW YORK TIMES INDEX. Several copies of the general library tour are also available, and other tapes on various indices are also in preparation.

Money for education has become scarce with several large federal cutbacks in the past year. A survey of the literature revealed that the "In" method for library orientation was the video-tape. This alternative was still beyond our financial means. Other institutions were experimenting with programmed cassette tours and seemed very pleased with the effective results and the rather inexpensive cost as compared to video-tape. A proposal was submitted to the Appalachian Ford Venture Grant Committee for the amount of $\$ 450$. This grant was approved and ten portable cassette recorders with headsets and 40 tapes were purchased to initiate the program. The particular recorder chosen can be carried around by its handle, but other units with shoulder straps are more practical in that they would free the patrons hands. It is also advisable to order standard brand-name equipment because of its quality and because if they need repair, one would not have to send them 2,000 miles for maintenance.

At first it was rumored that the Martians were invading Belk Library when everyone 
began noticing people walking around the various departments carrying the recorders and wearing bright green headsets. Our completed tape of the "Library Tour" uses the Love Story album for background music, and this certainly has appealed to many of the students. Two students displayed their ingenuity, however, by requesting one tour to be taped with "Blue Grass" and another with "Classical" music. Not only would this innovation guide the student through the library, but he could choose his musical preference.

Some of the students have commented about the stares they received when the program was first implemented. However, one day a young couple came in to take the tour for extra class credit and seemed to be oblivious to any of their surroundings. Every time they were observed they were laughing uproariously. Needless to say, when they returned their recorders, headsets, and tapes to the Reference Desk, I simply could not resist the urge to check the tapes. Either they had switched tapes, or they found the tour the most amusing piece of work in history.

It was expected that the program would require a minimum of financial assistance because after the initial purchase of equipment the scripts could be written and taped by library personnel. Publicity spread and more patrons and even staff were taking the tours. I would come in and find five of the ten recorders stacked on my desk with "Out of Order" notes attached to them. Technically, the only problem was dead batteries. Additional monies were made available for the project which made it possible to order a supply of nickelcadmium rechargeable batteries and five more recorders and headsets. This cut down on excessive use of any one or two recorders and has practically abolished those "Out of Order" signs.

Appalachian has no other formal program for library orientation, and we are still in the experimental stages. At this point, the tapes are supplementary to group instruction which is given by reference librarians upon request by a professor. This program offers the patron a chance to develop a skill in using a reference tool in an individual way. Although the physical arrangement of every library is different, a skill may be transferred from one library to another where the indices themselves and their purpose remain the same.

If someone needs an explanation on how to use ERIC or NEW YORK TIMES INDEX when a reference librarian is not on duty, he may sit down with the programmed tapes and follow through the example. Familiarization with the various materials is learned by working through a procedure of locating a particular topic such as "Abortion," "Drug Abuse," "Watergate," and "Noise Pollution." By spending 5-10 minutes with the tape and the index, it is possible for the patron to discover its usefulness and then continue searching for his specific topic.

Alternatively, tapes may be rewound and played again if any area needs to be reviewed, or the tape may be stopped, allowing the person to branch out on his own. Students use the tapes at their convenience and enjoy this new experience in their own experimental world of available information.

Opinionnaires were made available so that students could express their impression, as well as offer suggestions to improve the tapes. These opinionnaires have been very helpful in revising the tapes so that they are more informative and more easily understood.

One must keep in mind that everyone cannot be pleased. When one patron comments that not enough time is given for him to walk from one area to another, we console ourselves with the comment from another student who stated there was too much of a lag between the same areas. It is not uncommon to hear the surprised expression in a student's voice saying, "Hey, that's Love Story!" when he first turns on his recorder. Even if it is spoken loudly to compensate for not being able to hear one another for the headphones, it is appreciated. As one student wrote on the opinionnaire, and we hope it will continue to apply: "very unboring program!" 